Halse, Askill H. "More for everyone: The effect of local interests on spending on infrastructure." European Journal of Political Economy 43 (2016): 41-56.

(c) 2016. This manuscript version is made available under the CC-BY-NC-ND 4.0 license http://creativecommons.org/licenses/by-nc-nd/4.0/ 


\title{
More for everyone: The effect of local interests on spending on infrastructure
}

\author{
Askill H. Halse ${ }^{* \dagger \ddagger}$
}

February 23, 2016

\begin{abstract}
A central question in political economy is whether decision-making in representative democracies is biased towards local public investments or other types of policies which have locally concentrated benefits. The model by Weingast et al. (1981) predicts that a legislature with members from different areas will spend more in total on local public goods the smaller is the geographic constituency of each member. I test this prediction using panel data on the 18 Norwegian regional councils, exploiting that the geographic allocation of regional council seats varies considerably over time. Consistent with the theory, I find robust evidence that investments in regional public roads is lower when many council members come from the more populated areas in the region. This gives a more direct test of the prediction by Weingast et al. than existing empirical evidence, which concerns the relationship between public spending and legislature size. I find similar but less robust results for maintenance of existing roads.
\end{abstract}

Keywords: Concentrated gains, Common-pool, Distributive politics, Law of 1/n, Pork-barrel

JEL Classification: D72, H77, R40

*Tel.: +47 97178580 Email: a.h.halse@econ.uio.no

${ }^{\dagger}$ Department of Economics, University of Oslo, Postboks 1095 Blindern, NO-0317 Oslo, Norway

${ }^{\ddagger}$ Institute of Transport Economics (TØI), Gaustadalleen 21, NO-0349 Oslo, Norway 


\section{Introduction}

Can elected politicians' concern for their home districts lead to inefficient use of public funds? Many public policies mainly benefit those living in a particular area or region, while the costs are shared among all taxpayers. As a result, such policies could be favoured over other policies which would give higher total benefits, but which do not benefit any geographic area in particular.

This idea is explored in the model by Weingast et al. (1981), in which a body of elected representatives decide on the level of public goods allocated to each district. Each representative fully takes into account the benefits of spending in his or her own district, but only partly takes into account the opportunity cost. This leads to excessive total spending on local public goods at the expense of other purposes (or private consumption). If such forces are present in democratic decision-making, it could have strong implications for the design of political institutions and the allocation of responsibilities across different levels of government.

To properly test whether geographic fragmentation in the legislature causes higher aggregate spending on local public goods, one needs (1) decision-making bodies which incorporate conflicting geographic interests, (2) data on spending on policies with locally concentrated benefits and (3) a measure of legislature composition which captures the incentives of decision-makers to favour such policies. Of the existing empirical studies, most consider aggregate public spending and how this depends on legislature size (Gilligan and Matsusaka, 1995; Bradbury and Crain, 2001; Baqir, 2002; MacDonald, 2008; Egger and Koethenburger, 2010; Pettersson-Lidbom, 2012), which does not necessarily reflect to what extent narrow geographic interests (or other special interests) are represented in the decision-making. Some find that larger legislatures are associated with higher public spending, but the findings are mixed.

I look at policy decisions made by the elected councils in the 18 Norwegian regional governments, which cover large and geographically diverse areas. One of their main 
responsibilities is allocating funds to construction and maintenance of roads in different parts of the region. Regional council members are elected in at at-large proportional elections, which gives considerable variation over time in the shares of seats occupied by members from different areas of the region. To test the prediction that a lower relative population gives a stronger incentive to exploit the common pool (Saarimaa and Tukiainen, 2015), I look at how spending depends on the allocation of seats between areas (municipalities) with small and large population shares.

I find strong evidence that when seats in the regional council are more concentrated among representatives from the most populated municipalities, there are lower total investments in regional roads. The effect on maintenance of existing roads is less robust, but goes in the same direction. This is consistent with the hypothesis that elected representatives from more populated areas to a greater extent take into account the opportunity cost of spending on local public goods. There are no corresponding negative effects on spending in other sectors of the regional government.

The estimated effect of geographic seat concentration is statistically significant using approaches to statistical inference recommended for panel data analysis with a moderate number of clusters (Cameron et al., 2008; Hansen, 2007). Estimation with region fixed effects and a rich set of electoral control variables mitigates the concern for omittedvariable bias. The results are also robust to including spending on roads in the previous election period as a covariate.

The universalism assumption in the model by Weingast et al. implies that each representative completely free-rides on the other districts. This extreme assumption has been criticized, and the implications for aggregate spending are less clear-cut in models of non-cooperative legislative bargaining (Baron and Ferejohn, 1989; Persson and Tabellini, 2000, p. 165). Saarimaa and Tukiainen (2015) find evidence of free-riding behaviour in the temporary setting when municipalities have decided to merge but have not yet carried out the merger. My findings suggest that some kind of free-riding is also present in permanent democratic institutions, possibly because decision-makers or voters are 
more aware of the the benefits of local policies than their costs. ${ }^{1}$

I discuss the relevant literature in more detail in section 2. In section 3 , I describe the institutional setting of Norwegian regional politics and present the data. I then explain the empirical framework and present the results in section 4. Section 5 concludes.

\section{Related literature}

Weingast et al. (1981) analyze a model in which a legislature consisting of representatives from equally-sized districts allocate funding to local public projects in each district. Projects are funded by a common tax pool, leading to a common-pool problem: Each representative fully enjoys the benefits of a project in his or her district, but only party takes into account the cost. If representatives autonomously decide on spending in their own districts ('universalism'), this leads to overspending on local public projects at the expense of private consumption. The efficiency loss increases in the number of districts because the opportunity cost (tax share) of each district decreases. This is sometimes referred to as 'the law on $1 / \mathrm{n}$ '.

The relationship between legislative structure and aggregate public spending has been tested in several empirical studies, using legislature size (i.e. the number of seats) as the key explanatory variable. Baqir (2002) and MacDonald (2008) investigate whether a higher number of seats in U.S. municipal councils is associated with larger local governments. While Baqir finds a positive relationship when using cross-sectional variation, MacDonald shows that the estimated effect is smaller and not statistically significant when controlling for municipality fixed effects.

Pettersson-Lidbom (2012) analyzes spending by local governments in Sweden and Finland. He exploits that the number of seats changes discontinuously with the number of eligible voters (Sweden) or the size of the local population (Finland) and uses this to identify the causal effect of legislature size on spending. Pettersson-Lidbom finds some

\footnotetext{
${ }^{1}$ Peltzman (1976) considers a model where those who bear the cost of a policy do not necessarily oppose it.
} 
evidence that the effects on overall expenditures and public employment are in fact negative, and argues that this could be because a stronger local council is able to restrict the attempts by bureaucrats to increase the number of positions. Egger and Koethenburger (2010), on the other hand, find a positive effect on public spending and property taxes when applying a similar empirical strategy to data on Bavarian municipalities. ${ }^{2}$

Other scholars have studied higher levels of government. Gilligan and Matsusaka (1995) finds a positive effect of legislature size on spending for upper U.S. state houses. Bradbury and Crain (2001) finds a corresponding effect for lower chambers (and partly also for upper chambers) in a cross-country study of national legislatures. ${ }^{3}$

To what extent the number of seats is mapped with geographic representation depends on the electoral system. As pointed out by Saarimaa and Tukiainen (2015), the model by Weingast et al. considers the simple case of equally sized single-member districts. In this case, the number of seats is simply the inverse of district size. With unequally sized districts and/or multi-member districts, the link between district size and legislature size is not one-to-one. The municipalities studied by Pettersson-Lidbom and Egger and Koethenburger (and some of those studied by Baqir and MacDonald) have elections in which the whole municipality is one election district, so-called at large elections.

If geographic representation matters also in multi-member and at-large electoral systems, it could reflect that politicians favour their hometown also because they share interests with their co-citizens. Using data on the Norwegian regional governments and a regression-discontinuity design based on vote shares, Fiva and Halse (2015) find evidence that municipalities benefit if they are represented by a council member from the ruling party. It is however not clear that this would also apply to areas within smaller geographic units like local governments.

An electoral system is malapportionment if some districts are overrepresented (and

\footnotetext{
${ }^{2}$ Eggers et al. (2015) critically review the use of population thresholds in empirical applications. They find that there is often more than one policy changing at the threshold, and also that municipalities with population size close to a threshold sort strategically to one side of the threshold.

${ }^{3}$ Another branch of the literature concerns fragmentation of the cabinet, for instance the number of ministers or parties in a coalition government (Perotti and Kontopoulos, 2002; Schaltegger and Feld, 2009; Baskaran, 2013).
} 
others underrepresented) relative to their populations (Samuels and Snyder, 2001). Ansolabehere et al. (2002) study the effect of redistricting on transfers from U.S. states to their counties and find that representation matters for the distribution of transfers. ${ }^{4}$ However, when calculating an aggregate measure of malapportionment, they find no evidence that malapportionment affects aggregate transfers.

In the model by Weingast et al., each district representative autonomously decides ('universalism') on a level of local spending to be financed through joint taxation, implying that he or she completely free-rides on the other districts. If representatives instead have to form a majority coalition under non-cooperative bargaining, over-represented districts are likely to receive more benefits, but total spending is not necessarily higher than optimal (Knight, 2004; Persson and Tabellini, 2000, p.165).5 Motivated by this critique, Saarimaa and Tukiainen (2015) study the common pool problem in the case of municipal mergers. Here, free-riding is possible during the time between the merger is decided and carried out. They find that Finnish municipalities with small populations relative to their merger partners increase debt and use up cash reserves during the period period before the merger is carried through.

The studies by DelRossi and Inman (1999) and Knight (2004), which concern the preferences of individual decision-makers, take into account how costs are shared between districts. Both studies find that U.S. legislators' demand for local projects decrease in the local tax burden. As the authors of both studies point out, this is not only consistent with the model by Weingast et al., but also models of legislative bargaining. Nevertheless, DelRossi and Inman finds that the reform which increased local cost shares also led to lower total spending on water projects, and Knight finds that total spending on infrastructure is higher than the level which would be efficient according to the estimated

\footnotetext{
${ }^{4}$ Other studies which find a positive effect of representation on the distribution of public funds include those of Wright (1974) and Knight (2008) for the U.S., Horiuchi and Saito (2003) for Japan, Guccio and Mazza (2014) for Italy, Jennes and Persyn (2015) for Belgium and Helland and Sørensen (2009) for the Norwegian parliament.

${ }^{5}$ Persson and Tabellini (1994) show that the $1 / n$ result holds if decision-making is modeled as a lobbying process. In their model there is only one policymaker, but $n$ interest groups organized in lobbies.
} 
utility parameters.

Finally, several authors have pointed out that legislative structure has different implications for different types of spending. Both Weingast et al. and Baron and Ferejohn consider a public good which gives utility only to the district to which it is allocated. Besley and Coate (2003) show that if public goods have sufficiently high spillovers to other districts, centralized provision can increase efficiency. Milesi-Ferretti et al. (2002) distinguish between 'public goods', which can be targeted at all citizens living in a certain area, and 'transfers', which can more easily be targeted at groups which are not geographically based (e.g. age groups). They find that spending on public goods is higher in electoral systems with single-member districts.

\section{Institutional setting}

Norway has three levels of government, the national, the regional ('fylke') and the local ('kommune'). The two lower levels of government provide several important welfare services and together employ about 17 percent of the Norwegian labor force. I study policy outcomes in the 18 regional governments ${ }^{6}$, which have existed in their current form (with elections and a separate administrative level) since 1976. The median sized region has about 216,000 inhabitants spread across 15,000 square kilometers and 22 municipalities. In some regions, a large share of the population lives in the major city or its metropolitan area. In others, population is more evenly distributed among smaller cities and rural areas.

\subsection{Service provision}

The regional governments have several important responsibilities. Up until 2002, they were responsible for specialist health care, which was then transferred to the central government. Since then, the largest expense has been providing upper secondary education

\footnotetext{
${ }^{6}$ Norway has 19 regions including the capital Oslo, but Oslo does not have a separate regional government.
} 
to all youth in the region. Pupil admission is coordinated at the regional level. In some regions, pupils rank their preferred schools and fields of study and are allocated based on grades from lower secondary school. In others, pupils are allocated to the school offering their preferred field of study which is closest to where they live. In any case, many have to study outside their hometown to obtain the education they want. ${ }^{7}$

Furthermore, the regional governments are responsible for a large share (29.2 percent in 2009) of the Norwegian public road network referred to as the regional roads ('fylkesveger'). These roads are spread across all of Norway except two municipalities. The regional roads typically have less capacity than national roads ('riksveger') and are intended for intra-regional rather than inter-regional travel. They also vary considerably in quality: According to Statistics Norway's data on local and regional governments (KOSTRA), 9.3 percent of regional roads did not have an asphalt or concrete surface and 44.2 percent had 'poor or very poor' surface conditions in 2014.

In 2002 , the median regional government was responsible for a network of 1,586 kilometers of roads. Today this number is 2,482 kilometers, after the central government in 2010 granted the regions responsibility for national roads which were not considered part of the national trunk road network ('stamveger') The other responsibilities include public transportation (since 1981), cultural services, dental care as well as some planning and measures to promote regional development.

To motivate the analysis in the following section, I present in Table 1 some aggregate statistics on the allocation of regional government facilities and services. The sample of municipalities is split into three population quantiles. We see that the largest municipalities account for only about twice as much regional roads as the smallest, despite being many times larger in population. This also holds for investments in new roads, which I proxy for using meters of new bridges on regional roads. ${ }^{8}$

\footnotetext{
${ }^{7}$ Since 1994, all Norwegian youth have the right to upper secondary education.

${ }^{8}$ The small average figures (2,5 meters of bridge per year in small municipalities) reflect that investments in this road network often do not imply large constructions above ground. Data on the geographic allocation (within regions) of road investments or other components of regional government spending are in general not available. Fiva and Halse (2015) use data on refunds for investments which are carried out in cooperation between the local and regional government to study how political representation affects
} 
Table 1: Existing and new local facilities which are funded by the regional government, split by municipality population tertile

\begin{tabular}{lrrr}
\hline & $\begin{array}{r}\text { Small pop. } \\
\text { (means) }\end{array}$ & $\begin{array}{r}\text { Medium pop. } \\
\text { (means) }\end{array}$ & $\begin{array}{r}\text { Large pop. } \\
\text { (means) }\end{array}$ \\
\hline Population, 1980-2014 & 1,765 & 4,561 & 21,387 \\
Regional roads, 2002 (km) & 43.69 & 61.67 & 85.45 \\
Regional roads, 2010 (km) & 75.11 & 105.71 & 130.32 \\
New road bridges, 1980-2014 (m) & 2.48 & 4.61 & 5.74 \\
Has at least one hospital, 2000 (dummy) & 0.01 & 0.03 & 0.38 \\
Births in local hospital, 1980-1998 & 1.98 & 6.86 & 324.29 \\
Upper secondary schools, 1980-2012* & 0.30 & 0.70 & 2.60 \\
Public upper secondary schools, 2001-2012 & 0.15 & 0.50 & 1.82 \\
Pupils in upper secondary schools, 1980-2012 & 25 & 1382 & 1,018 \\
Gets +1 upper sec. school, 1980-2012* (dummy) & 0.01 & 0.01 & 0.05 \\
\hline Observations & 5005 & 4979 & 4983 \\
\hline
\end{tabular}

$\left.{ }^{*}\right)$ The number of schools is missing for the years 1995-2000.

Note: Data on road bridges are from the BRUTUS database of the National Public Roads Administration. Hospitals are extracted from the report by Hansen (2001) and births from the Medical Birth Registry of Norway. Municipality-level data on upper secondary schools for 2001-2012 were provided on demand by Statistics Norway. The remaining data is from official statistics. 
Hospitals and births in hospitals (before the 2002 reform) are much more concentrated to the larger municipalities. The same goes for upper secondary schools, especially the number of pupils, which is about 40 times larger in the largest municipalities than in the smallest. As a rough proxy for building of new schools, I use whether the municipality has more local upper secondary schools than in the previous year. This variable is less dramatically concentrated to the largest municipalities, but still more than roads and road investments. Considering the heavy geographic concentration of pupils and the fact that education is less capital intensive (see next section), most of the money spent on upper secondary schooling will go to the most populated areas.

\subsection{Representation and decision-making}

The decision-making body in the regional governments is the regional council ('fylkesting'). The council has between 33 and 85 members and makes decisions by majority voting. In most regions, decisions are prepared by an executive board ('fylkesutvalg') consisting of the regional mayor and other senior council members elected by the council, and implemented by an appointed administration. (This is often referred to as the 'aldermen model'.) Normally, all or most political parties are also represented in the executive board. Since 1999, four regions ${ }^{9}$ have adapted a 'parliamentarian' model in which decisions are prepared and implemented by a political administration representing the ruling coalition, similar to the national government.

Elections are held every forth year on the same day as local government elections. Most candidates represent one of the seven major parties regularly represented in the Norwegian parliament ${ }^{10}$, but smaller parties and independent electoral lists occasionally succeed in winning seats. Elections take place with the region as one electoral district (at large elections), and seats are allocated proportionally between parties to candidates

the distribution of spending.

${ }^{9}$ Nordland region since 1999 and Hedmark, Nord-Trøndelag and Troms since 2003.

${ }^{10}$ The Norwegian Labour party, the Conservative party, the Progress party, the Center party, the Christian Democrats, the Liberal party and the Socialist Left party. 
based on their ranking on the ballots. ${ }^{11}$

While each council member does not formally represent a specific district, his or her home municipality is normally reported on the ballot. In elections before $2003,1 / 6$ of the seats in the regional council were reserved for candidates from municipalities which did not occupy any seats once the other $5 / 6$ had been allocated. ${ }^{12}$ In 2003 the seat reservation system was abolished, which means that many municipalities are not guaranteed a seat in the council.

There are many examples from local media showing that council members act as representatives of their home municipalities in the decision-making:

- In a council meeting in Nordland region, council member Johan Petter Røssvoll from Rana municipality asks the executive of transport for plans to upgrade two regional road links in Rana which have a worn down surface and insufficient lighting. (Rana Blad, 2013.06.04)

- Commenting on Nordland regions four-year economic plan, council member Knut Petter Torgersen from Vefsn municipality is happy that a new ferry terminal will be built in Vefsn. Torgersen, who says that he has been working on this for a long time, is also the director of the municipality enterprise for business development. (Helgelendingen, 2013.11.06)

- In Vest-Agder region, council member Nils Harald Rennestraum from Kvinesdal states that he 'does not accept' the regional administration's proposal to postpone upgrading a regional road in Kvinesdal. (Avisen Agder, 2011.11.19)

- In Finnmark region, the council votes against including building of a new dental clinic in Kautokeino in the regional plan for dental care. Council member Mikkel Isak Eira from Kautokeino municipality then proposes to allocate funding for the

\footnotetext{
${ }^{11}$ From 2003, voters may cast personal votes for individual candidates ('open list'), but a large number of personal votes is required to alter the candidate ordering. Christensen et al. (2004) find that personal votes had only a marginal impact in the 2003 election.

${ }^{12}$ This arrangement did not affect the allocation of seats between parties, which was based on vote shares both for reserved and non-reserved seats (using Sainte-Leaguë's modified rule).
} 
clinic as part of the budget revision the next day. The funds are allocated and the clinic is built. (NRK Sami Radio, 2014.05.08)

Every autumn, the regional council votes over the budget for the following year. The regional government can take up loans to finance investments, but the net operating surplus is required to be non-negative. The revenue side of the budget mainly consists of grants from the central government and a fixed share of the national income tax. Unlike the local governments, the regional governments do not collect local property tax and only in a few cases user fees.

This implies that politics matters for the composition and to some extent the timing of regional public spending, but not the size of the regional government. For details on the fiscal framework within which local and regional governments operate, see Borge (2005), Borge and Tovmo (2009) and Borge et al. (2014).

\section{Data}

I employ data on public spending, elections, representation and population characteristics in all 18 Norwegian regional governments from 1980 to 2014. This is the entire period during which this level of government has existed in its present form, except for the first four years. ${ }^{13}$ Below, I first describe the data on policy outcomes and then the data on political representation.

\subsection{Spending variables}

Detailed data on spending decisions made by the regional governments are extracted from the accounting data collected by Statistics Norway (SSB). This data allows us to study the yearly allocation across sectors as well as between investments and operating expenditures within each sector. I employ data on operating expenditures and investments for the

\footnotetext{
${ }^{13}$ I exclude the election period 1976-1979 because some municipalities split in 1977, making it impossible to identify the hometowns of council members from these municipalities for this electoral period.
} 
Figure 1: Components of regional government spending, all regions

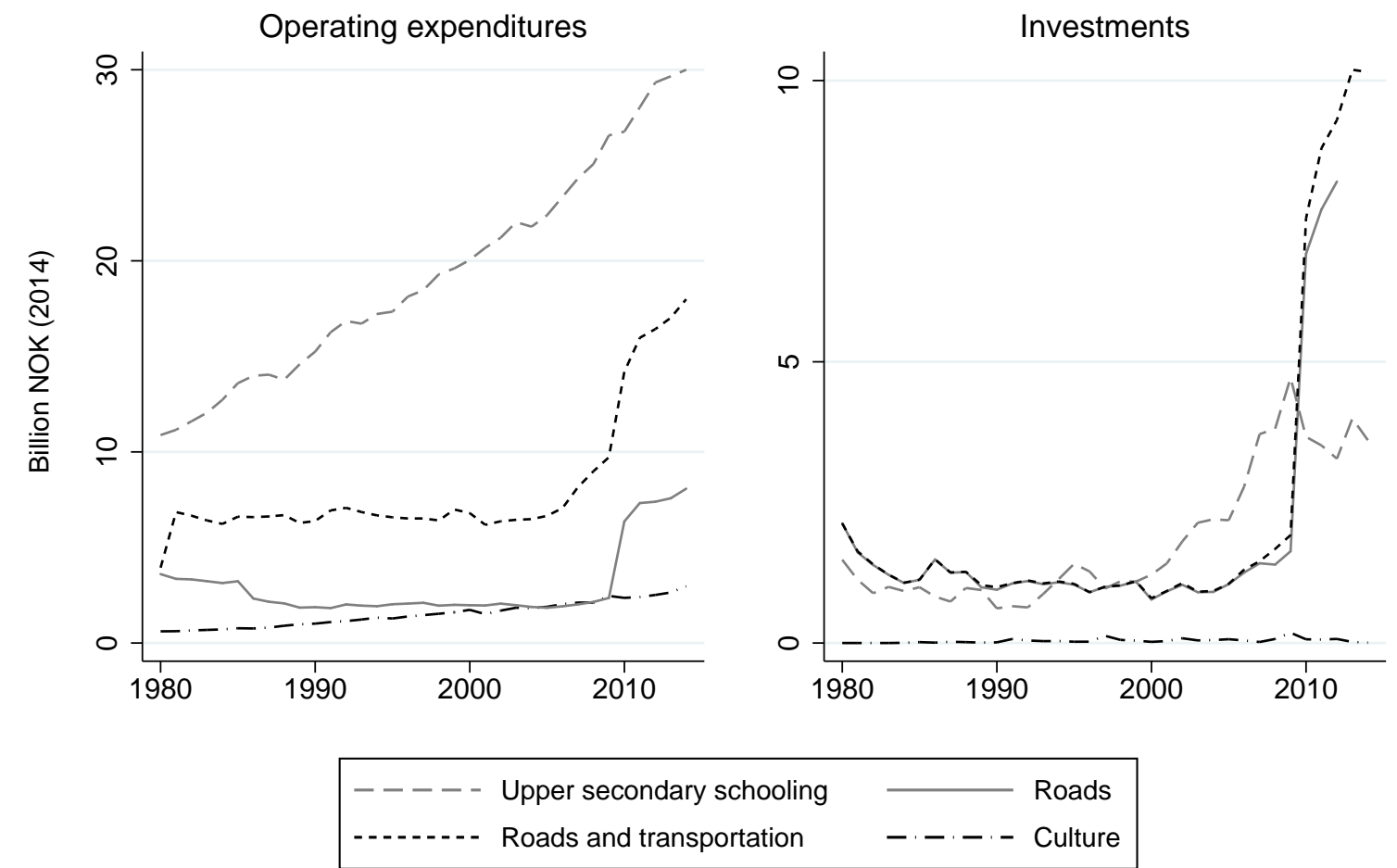

Note: 'Roads and transportation' includes roads as well as local and regional public transportation. Investments in roads only are not available for 2013-2014.

sectors (1) upper secondary education, (2) roads and transportation and (3) culture, for which the regional governments have been responsible throughout the sample period. Together, these three sectors accounted for 81 percent of regional government spending in 2008, and an higher share after 2010.

For most sample years, spending on roads and transportation can be divided into spending on regional public roads and spending on other transportation policies (mainly public transportation). In the case of operating expenditures, I have data on expenditures for roads for the whole sample period, but road investments are not available for 20122014. In figure 1, which shows all components of regional public spending, we see that almost all investments in roads and transportation are investments in roads. ${ }^{14}$

\footnotetext{
${ }^{14}$ Transfers to a public transport operator owned by the regional government will show up as operating expenditures, even if these transfers constitute funding of an investment (e.g. new rolling stock).
} 
As expected, investments are relatively more important in the case of roads, while spending on upper secondary schooling and culture is dominated by operating expenditures. We also see that while spending on schools and culture has increased steadily, spending on roads and transportation did not increase much before 2010. It then jumped as a result of the reform mentioned in section 3.2, which made the regions responsible for a larger network of public roads. Accounting for this reform will hence be important in the empirical analysis.

\subsection{Electoral variables}

Data on all regional elections 1979-2011 are available in official statistics. The statistics are reported on the municipality level and shows how many council members come from each municipality in the region ${ }^{15}$, their party affiliation and their gender. It also contains the votes for each party and which party holds the governor ('fylkesordfører)' position after the election.

Our main object of interest is the allocation of seats between different municipalities in the region. This is determined by

1. the allocation of seats between parties

2. parties' ranking of candidates from different areas

3. the seat reservation system which was in place until 2003

4. the total number of council seats, which has decreased over time in most regions

As an illustration of the variation over time, figure 2 shows the geographic distribution of population and council seats in the region Hordaland after the 1995 and 2011 elections.

\footnotetext{
${ }^{15} 41$ municipalities have merged during the period. In the analysis I keep the municipality structure fixed to the 2014 structure for all years, hence assuming that council members from the 41 old municipalities represent the 15 new and larger municipalities to which they would later belong. Although mergers could potentially affect which areas the council members identify with, we would not want this to drive the results. The only change in the regional structure is when Ølen municipality changed regional affiliation from Hordaland to Rogaland region in 2002, before merging with its neighbor Vindafjord. Hordaland therefore has one municipality less after 2002.
} 
Figure 2: Distribution of population and regional council seats in Hordaland region

\section{5 election}

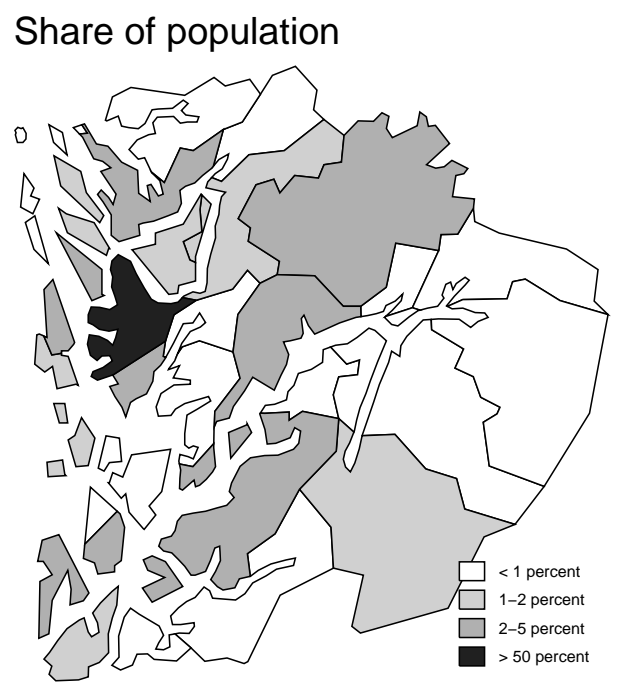

Share of seats in regional council

\section{1 election}

Share of population

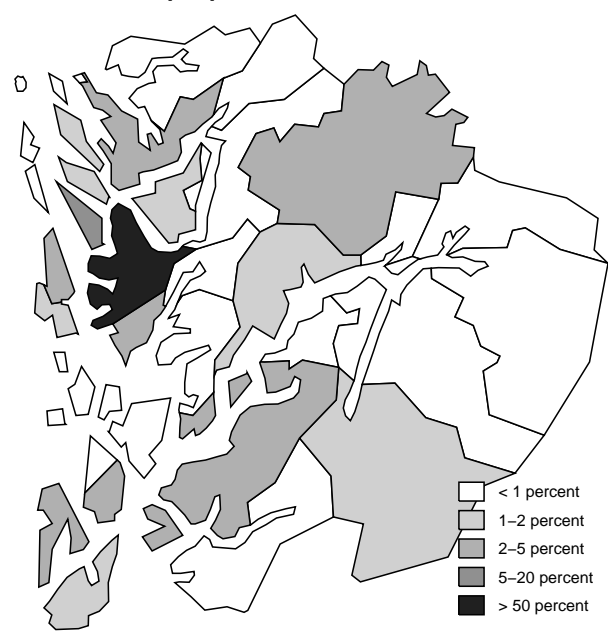

Share of seats in regional council

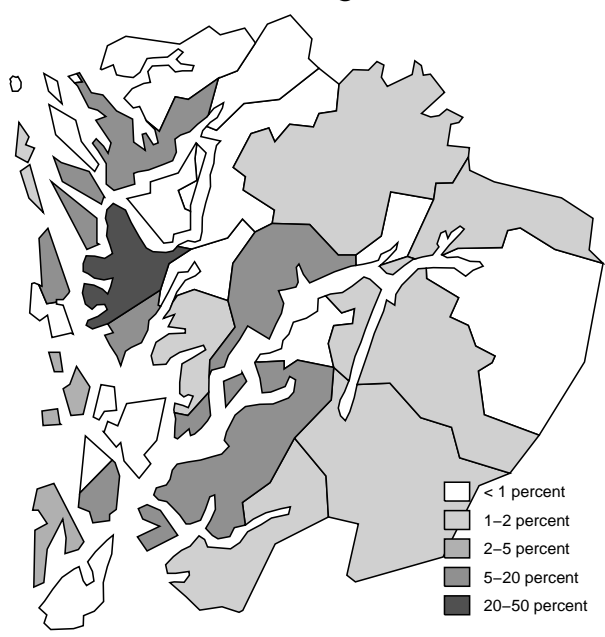

Note: The maps to the left show the share of the regional population each municipality accounts for. The maps to the right show the share of seats each municipality occupies in the regional council. 
We see that that seats are distributed much more evenly than inhabitants: While the city of Bergen accounts for more than half ( 52.5 percent) of the region's population and several municipalities account for less than a percent, most of the 34 municipalities occupied at least 1-2 percent of the seats after the 1995 election. ${ }^{16}$ After the 2003 electoral reform, several sparsely inhabited municipalities were no longer represented in the council. However, Bergen is still under-represented with respect to population.

In the next section, I use the distribution of seats to construct region-level measures of the influence of municipalities with small and large populations, and investigate how this impacts spending decisions.

\section{Empirical analysis}

To test whether geographic political fragmentation leads to higher spending on local public goods, we need:

1. A dependent variable capturing spending on policies which can be targeted at particular areas ('local public goods')

2. A region-level measure of geographic fragmentation which captures the incentives of politicians to support such policies

The main dependent variable of interest is investment in roads and transportation. Such investments are likely to have locally concentrated benefits, and Table 1 documents that they often benefit less populated areas. In general, politicians have high discretion when it comes to the local level of road quality or whether a new road connection should be built. The studies by Knight (2004, 2005, 2008), Castells and Solé-Ollé (2005) and Helland and Sørensen (2009) document that infrastructure investment is a policy area in which geographic interests and legislative representation are important. However, I also include outcomes for the others sectors shown in section 4.1.

\footnotetext{
${ }^{16}$ The figure shows that two municipalities did not obtain a seat, despite of the seat reservation system in place until 2003. As only $1 / 6$ of the seats were reserved, full representation was not guaranteed.
} 


\subsection{Measuring geographic fragmentation}

The opportunity cost of spending on local public goods is less money available for other spending purposes. ${ }^{17}$ This opportunity cost is higher for those representing an area with more inhabitants. I therefore follow Saarimaa and Tukiainen (2015) and construct an explanatory variable based on relative municipality size. ${ }^{18}$ More specifically, I measure the population share of the municipality in which the average council member lives and label this seat concentration:

$$
\text { Seatconc }_{r t}=\sum_{i}\left(\frac{\text { Pop }_{\text {irt }}}{\sum_{i} \text { Pop }_{\text {irt }}}\right) \cdot\left(\frac{\text { Seats }_{\text {irt }}}{\sum_{i} \text { Seats }_{\text {irt }}}\right)
$$

Here, Pop $_{\text {irt }}$ is the population and Seats irt $_{\text {is }}$ the number of council members from municipality $i$ in region $r$ at time $t$.

As a numerical illustration, consider a region with 21 municipalities and 25 seats in the regional council. The largest municipality accounts for 40 percent of the population, while the remaining 20 account for 3 percent each. If the largest municipality has five council seats and the others one each, seat concentration is $0.4 \cdot 5 / 25+20 \cdot 0.03 \cdot 1 / 25=0.104$. If half of the small municipalities lose their seats to the large one, Seatconc $c_{r t}=0.4 \cdot 10 / 25+$ $10 \cdot 0.03 \cdot 1 / 25=0.172$. The 'average council member' now represents a municipality which has 17.2 percent of the regional population.

As shown in the previous section, the electoral system implies that not all municipalities always occupy a seat in the council. This could affect policy decisions, for instance by changing the set of possible geographic alliances which council members can form. To account for this possibility, and because it is likely to be correlated with the measure above, I include the share of municipalities with at least one council seat (Sharerep $r$ ) as an explanatory variable.

How population is distributed within the region will affect Seatconc $c_{r t}$, both mechan-

\footnotetext{
${ }^{17}$ In the paper by Weingast et al. (1981), the opportunity cost is lower private consumption. This is less relevant here, since the regions cannot set the tax level

${ }^{18}$ The measure used by Saarimaa and Tukiainen is not aggregated over municipalities, since they study the incentives of each individual municipality.
} 
Figure 3: Geographic concentration of council seats and population within each region

\section{5 election}
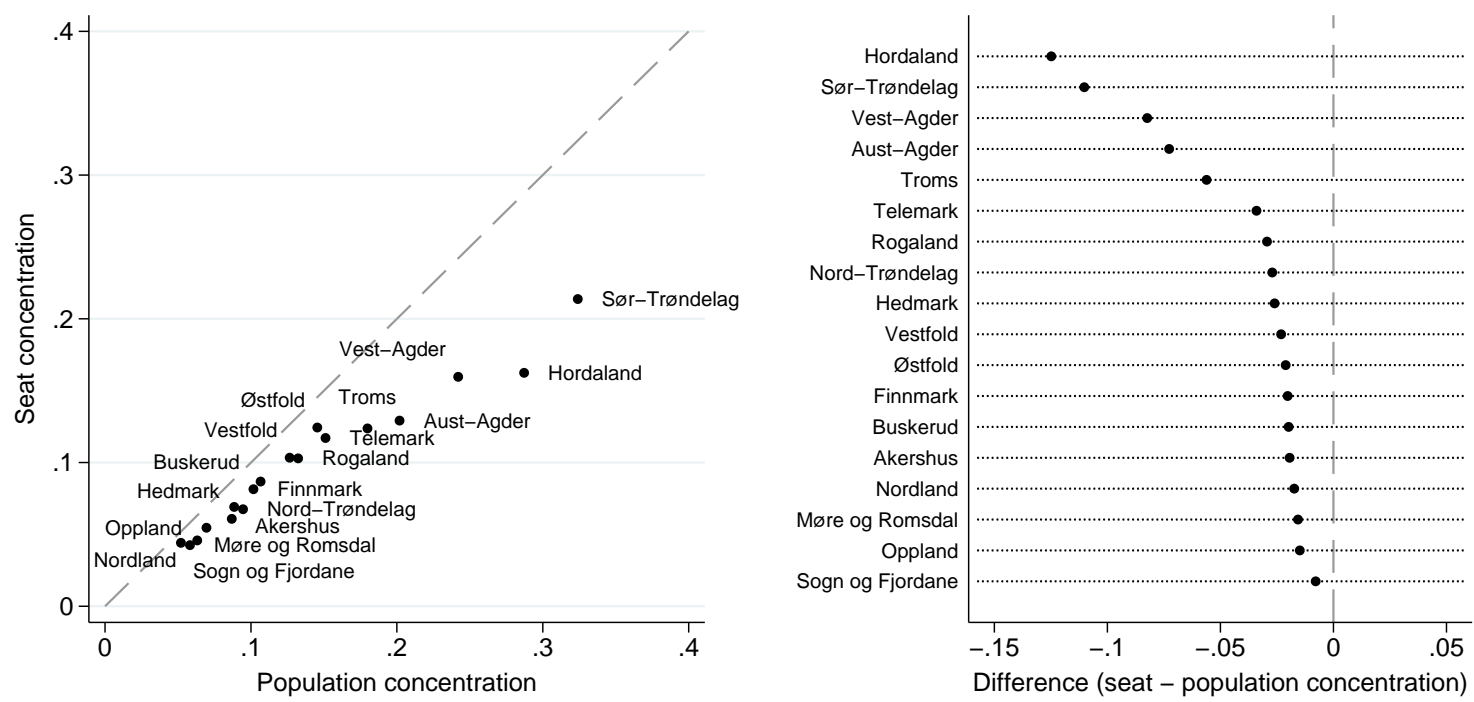

\section{1 election}
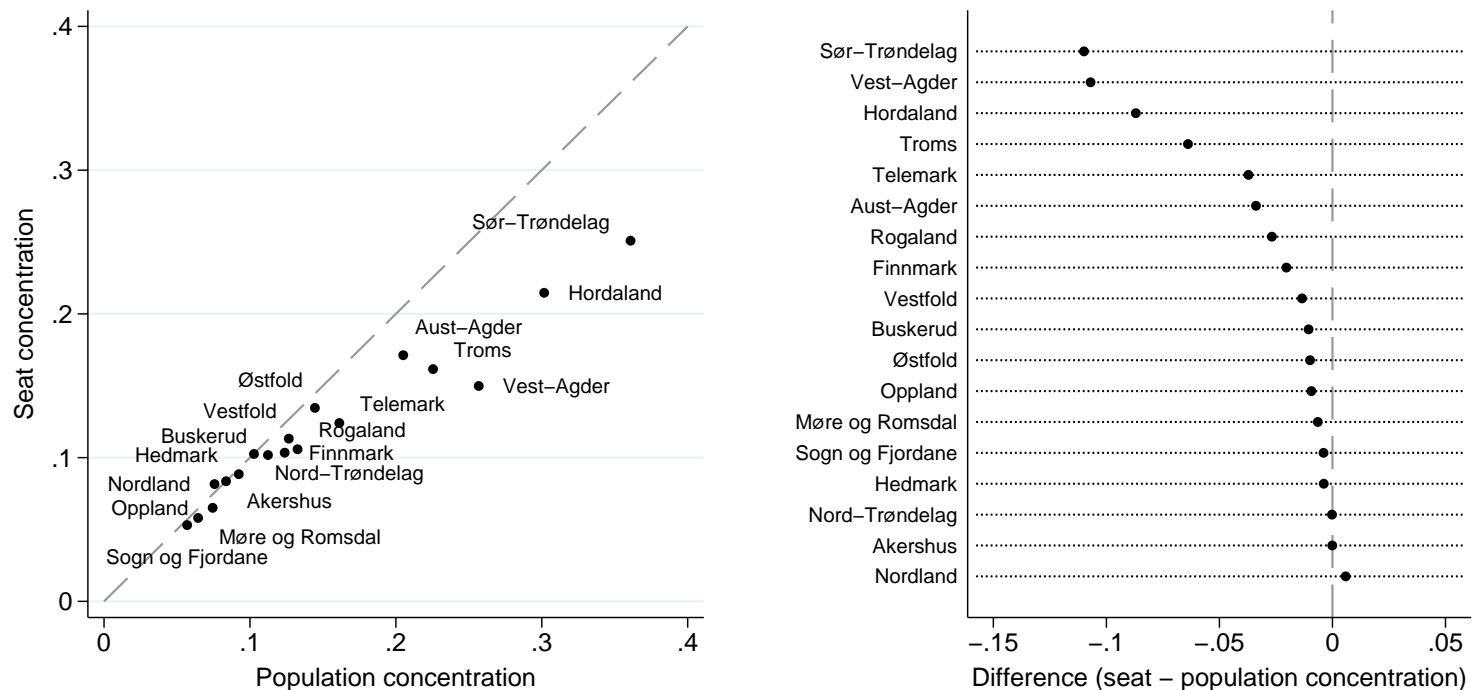

Note: The vertical axis of the left panels shows average population share of municipalities in the region, weighted by the share of regional council members from each municipality. The horizontal axis shows the average squared population share. The right panels plot the difference between the two. 
ically (through the population weights) and because a higher population might increase the probability of representation. To account for a possible direct effect of population structure, I include a Herfindahl index measuring population concentration ${ }^{19}$ :

$$
\text { Popconc }_{r t}=\sum_{i}\left(\frac{\text { Pop }_{\text {irt }}}{\sum_{i} \text { Pop }_{\text {irt }}}\right) \cdot\left(\frac{\text { Pop }_{\text {irt }}}{\sum_{i} \text { Pop }_{\text {irt }}}\right)=\sum_{i}\left(\frac{\text { Pop }_{\text {irt }}}{\sum_{i} \text { Pop }_{\text {irt }}}\right)^{2}
$$

This index is equivalent to the seat concentration index, except that each municipality is weighted by its population instead of its share of council seats. Figure 3 shows both indexes for all regions after the 1995 and 2011 elections. We see that seats are equally or more concentrated than population in almost all regions, but that this discrepancy varies over time within regions. The most populated municipalities in the regions Hordaland and Aust-Agder are less under-represented in 2011 than in 1995, while the opposite is the case in Vest-Agder region.

If high spending on local public goods can be explained by free-riding incentives of council members from areas with low populations, Seatconc $c_{r t}$ should capture the presence of such incentives in the council. This does however not imply that other measures of council size of composition could not partly capture the same mechanism, or capture other important factors in decision-making. In section 5.4, I compare the results when using some alternative measures.

\subsection{Model specification and estimation}

Using the measure of seat concentration derived above, I estimate the following model of regional government spending per capita, measured in fixed (2014) prices:

\footnotetext{
${ }^{19}$ One way of reducing the correlation between the two variables would be to use a time-invariant measure of population in (1). However, given the long sample period, accounting for time variation in Pop $_{\text {irt }}$ is desirable.
} 


$$
\ln \left(\text { spending }_{\text {srt }}\right)=\alpha_{s r}+\theta_{s t}+\beta_{s} \cdot \text { Seatconc }_{r t}+\lambda_{s} \cdot \text { Sharerep }_{r t}+\gamma_{s} \cdot \mathbf{z}_{r t}+\varepsilon_{\text {srt }}
$$

where $s$ denotes sector, $r$ region and $t$ year. $\mathbf{z}_{m t}$ is a vector of time-varying control variables which could be correlated with geographic seat concentration and spending. The $\alpha_{s r}$ are region fixed effects, and the $\theta_{s t}$ are time fixed effects.

When estimating the model, serial correlation of the $\varepsilon_{\text {srt }}$ over different years for the same regional government has to be taken into account. The standard approach is to use cluster-robust standard errors, but there is some discussion in the literature regarding the how many clusters $(G)$ are sufficient. According to Cameron et al. (2008), $G=18$ is too low when using clustering to adjust for within-group correlation. Hansen (2007), considering only serial correlation, finds that the standard approach works reasonably well with as few as 10 cross-sectional units. However, he recommends to do inference based on a $t$-distribution with $G-K$ degrees of freedom, $K$ denoting the number of parameters (not including the constant term). Below, I evaluate statistical significance using both approaches.

The vector of control variables is kept relatively parsimonious for the following reasons: First, the moderate sample size implies that with a rich set of controls we run the risk of over-fitting the model to the data. Second, 17 parameters or less is necessary for the approach advocated by Hansen to be valid. In my main specification, I therefore restrict the time fixed effects to be constant within each electoral period. The exception is the period 2008-2011, where I include one extra dummy for $t>2010$ to account for the decentralization reform in which the regions became responsible for a larger network of roads. In the robustness checks, I include more electoral control variables and a full set of year fixed effects, and estimate the model using election periods as the observational unit. $^{20}$

\footnotetext{
${ }^{20}$ Using years as the observational unit in the main analysis is more convenient since one year (2015) is not included in the last 4-year period and since the 2010 road decentralization reform was implemented
} 
In the preferred specification, I control for Sharerep $_{r t}$, Popconc Prt $_{r}$, (log) population size and the $(\log )$ length of the regional road network. ${ }^{21}$ (When region fixed effects are included, only the increase in road kilometers in 2010 matters.) I also control for total spending per capita to account for fiscal capacity.

\subsection{Results}

Table 2 shows the results with investment in transportation as the dependent variable. In the first column, I report the results without region fixed effects and seat concentration as the only explanatory variable. Since cross-sectional variation in Seatconc $r t$ also comes from municipality and population structure, this model is likely to be too naive. The estimated effect is negative, consistent with the prediction that politicians from more populated municipalities prefer less spending on local public goods. However, it is not statistically significant.

With control variables (column 2) or region fixed effects (column 3), the estimated effect of seat concentration becomes stronger and/or more precise. When including both (column 4), the standard error decreases even further, and the effect is statistically significant on the five percent level based on the wild bootstrap procedure of Cameron et al. (2008). Applying a $t$-test with $G-K=4$ degrees of freedom as advocated by Hansen (2007) leads to the same conclusion.

When I include also the number of municipalities with at least one member in the regional council (column 5), this variable has a negative estimated effect. It is not clear what we should expect here, since the theoretical literature reviewed above deals with settings were all districts are represented. The effect of this variable is also not very robust. However, since it negatively correlated with seat concentration over time, the

\footnotetext{
between elections (in 2010).

${ }^{21}$ For this, I use the length measured in 2002 and 2010, respectively. Variation in road km within the pre-reform (1980-2009) and post-reform period (2010-2014) is small and likely to be endogenous. (Investments could result both in new road links and shortening of existing links.) Burgess et al. (2013) use construction of entirely new road links as outcome variable in their study of ethnic favoritism in Kenya.
} 
Table 2: The effect of geographic seat concentration in the regional council on regional government investments in roads and transportation

\begin{tabular}{|c|c|c|c|c|c|c|c|}
\hline & $\begin{array}{l}\text { (1) } \\
\text { OLS }\end{array}$ & $\begin{array}{l}\text { (2) } \\
\text { OLS }\end{array}$ & $\begin{array}{l}(3) \\
\mathrm{FE}\end{array}$ & $\begin{array}{l}(4) \\
\mathrm{FE}\end{array}$ & $\begin{array}{l}(5) \\
\mathrm{FE}\end{array}$ & $\begin{array}{l}\text { (6) } \\
\mathrm{FE}\end{array}$ & $\begin{array}{l}\text { (7) } \\
\mathrm{FE}\end{array}$ \\
\hline Seat concentration & $\begin{array}{r}-3.49 \\
(2.60)\end{array}$ & $\begin{array}{r}-8.85^{* * *} \\
(2.59)\end{array}$ & $\begin{array}{l}-4.61^{*} \\
(2.26)\end{array}$ & $\begin{array}{r}-5.16^{* * *} \\
(1.57)\end{array}$ & $\begin{array}{r}-7.23^{* * *} \\
(2.19)\end{array}$ & & $\begin{array}{r}-6.88^{* *} \\
(2.56)\end{array}$ \\
\hline Share with $\geq 1$ rep. & & & & & $\begin{array}{l}-1.10^{*} \\
(0.58)\end{array}$ & $\begin{array}{r}-0.76 \\
(0.58)\end{array}$ & $\begin{array}{r}-1.09 * \\
(0.56)\end{array}$ \\
\hline Reps. from islands & & & & & & & $\begin{array}{r}0.39 \\
(2.22)\end{array}$ \\
\hline Roads per representative & & & & & & & $\begin{array}{r}-1.49 \\
(12.28)\end{array}$ \\
\hline Area per representative & & & & & & & $\begin{array}{r}2.53 \\
(10.65)\end{array}$ \\
\hline Pop. concentration & & $\begin{array}{c}3.88^{* *} \\
(1.53)\end{array}$ & & $\begin{array}{r}2.05 \\
(3.85)\end{array}$ & $\begin{array}{r}1.49 \\
(3.89)\end{array}$ & $\begin{array}{r}-4.00 \\
(4.50)\end{array}$ & $\begin{array}{r}1.36 \\
(4.15)\end{array}$ \\
\hline $\ln$ (population) & & $\begin{array}{r}0.20 \\
(0.16)\end{array}$ & & $\begin{array}{r}1.39 \\
(1.21)\end{array}$ & $\begin{array}{r}1.37 \\
(1.23)\end{array}$ & $\begin{array}{r}1.30 \\
(1.24)\end{array}$ & $\begin{array}{r}1.40 \\
(1.30)\end{array}$ \\
\hline $\ln$ (total spending per cap) & & $\begin{array}{r}0.41^{* * *} \\
(0.13)\end{array}$ & & $\begin{array}{r}0.24 \\
(0.14)\end{array}$ & $\begin{array}{r}0.23 \\
(0.14)\end{array}$ & $\begin{array}{r}0.24 \\
(0.14)\end{array}$ & $\begin{array}{r}0.23 \\
(0.14)\end{array}$ \\
\hline 2010 reform & $\begin{array}{r}1.46^{* * *} \\
(0.10)\end{array}$ & $\begin{array}{r}1.21^{* * * *} \\
(0.09)\end{array}$ & $\begin{array}{r}1.46^{* * *} \\
(0.10)\end{array}$ & $\begin{array}{r}1.42^{* * * *} \\
(0.27)\end{array}$ & $\begin{array}{r}1.35^{* * *} \\
(0.30)\end{array}$ & $\begin{array}{r}1.34^{* * *} \\
(0.30)\end{array}$ & $\begin{array}{r}1.35^{* * *} \\
(0.35)\end{array}$ \\
\hline $\ln ($ road km) & & $\begin{array}{r}0.33^{* *} \\
(0.14)\end{array}$ & & $\begin{array}{r}-0.06 \\
(0.55)\end{array}$ & $\begin{array}{r}0.08 \\
(0.63)\end{array}$ & $\begin{array}{r}0.10 \\
(0.63)\end{array}$ & $\begin{array}{r}0.06 \\
(0.77)\end{array}$ \\
\hline
\end{tabular}

$\ln ($ area $)$

$0.38^{* * *}$

$(0.08)$

$\ln (\mathrm{km}$ coastline $)$

$0.06^{* *}$

$(0.02)$

No coastline

$-0.27$

$(0.19)$

$p$-value of Seat concentration

0.200
0.48
630
No
Yes

0.004

0.066

0.028

0.030

0.092

(Within) R-squared

0.72

0.64

0.64

0.65

0.64

0.65

No. of observations

No Yes

630

630

$630 \quad 630$

El. period fixed effects

Yes Yes

Yes Yes

Note: The dependent variable is log NOK per capita investments in roads and transportation by the regional government. Seat concentration is the average population share of the home municipalities of the members of the regional council. The p-values of seat concentration reported are based on the wild bootstrap procedure of Cameron et al. (2008). Standard errors in parentheses and corresponding significance stars are adjusted for clustering at the region level. 
effect of the latter increases somewhat when both are included. Similarly, the estimated effect of the share with at least one seat is weaker when only this variable is included (column 6).

The preferred specification in column (5) shows a negative and statistically significant effect of Seatconc $c_{r t}$ on public spending which is also economically significant: If the population share of the home municipality of the average council member increases by 1 percentage point (about $1 / 5$ of a standard deviation ${ }^{22}$ ), investments in roads and transportation per capita decrease by 7.2 percent (about $1 / 15$ of a standard deviation). This supports the prediction by Weingast et al. (1981) that spending on local public goods is lower the larger is the geographic constituency of each representative.

In the theoretical model, politicians representing a smaller population favour more spending on local public goods because they care less about the opportunity cost. While it is difficult to address this mechanism explicitly, we can test whether the results change when we include other characteristics of council members' hometowns. Column (4) shows that the effect is not driven by whether the politician's home municipality is an island, or by its area or amount of regional roads. ${ }^{23}$ This gives some indication that it is relative size in itself that matters and not other characteristics.

In table 3 , I show the results for the other components of regional public spending. (Investments in culture are not included, as they are low and often zero.) As expected, the effect on investment in roads only (1980-2012) in column 5 is similar to that for roads and transportation. Looking at operating expenditures, we also see a negative effect for roads (column 2). This indicates that politicians from small municipalities do not only favor new road investments which are visible to voters (Drazen and Eslava, 2010), but also maintenance of of existing roads. This effect is however not statistically significant at the ten percent level based on wild bootstrap, or based on a $t$-test with $G-K=3$

\footnotetext{
${ }^{22}$ The overall standard deviation is 0.049 . The standard deviation based on time variation only is 0.013 .

${ }^{23}$ Like Seatconc $c_{r t}$, these are measured in relative shares. Including both population share and area share implies that we effectively control for whether council members come from municipalities with high population densities.
} 
degrees of freedom. Hence, we should be careful concluding. ${ }^{24}$

Roads seems to be the only spending purpose which is favored less by council members from the more populated municipalities. The estimated effect on total operating expenditures for roads and transportation together (column 1) is not statistically significant and close to zero. The same holds for operating expenditures for upper secondary schools (column 3). The effect on spending on cultural services (column 4) is positive, but not statistically significant. The effect on investments in upper secondary schools (column 6) is large and positive, but very imprecisely estimated. ${ }^{25}$

Overall, the results give support for the hypothesis that politicians from less populated areas favor higher spending on local public goods, and that lower representation of such politicians result in lower spending on such goods. The results also indicate that the effect is driven by relative population size, capturing the free-riding incentive, and not correlated characteristics.

\subsection{Validation}

The strength of the empirical strategy is that all time-invariant characteristics of the regional governments are accounted for through the region fixed effects. However, since the geographic allocation of council seats depends on the electoral result, one could worry about omitted election-specific variables or potentially a reverse causal link going from policies or policy promises to representation. There could also be other confounding factors like settlement pattern. In this section, I discuss and address these issues.

As explained in section 5.1, population concentration is included in the baseline models in order to account for changes in settlement pattern correlated with council seat

\footnotetext{
${ }^{24}$ If I do not control for total spending (which is a very poor predictor in this model) the results are virtually unchanged, and the effect of seat concentration is statistically significant at the ten percent level based on a $t$-test with $G-K=4$ degrees of freedom. Nordland region is omitted for one year when its operating expenditures for rods are falsely recorded as zero.

${ }^{25}$ Since the variable is in logarithms, 1000 NOK are added because two observations have zero investments in schools. Akershus region is omitted for the years 2011-2014 in columns (3) and (6), because since 2011 its investments in schools are handled by a company owned by the regional government and hence show up as operating expenditures.
} 
Table 3: The effect of geographic seat concentration in the regional council on components of regional government spending

\begin{tabular}{lrrrrrr}
\hline & \multicolumn{3}{c}{ Operating expenditures } & \multicolumn{3}{c}{ Investments } \\
& Roads/transp. & Roads & Schools & Culture & \multicolumn{1}{c}{ Roads } & Schools \\
\hline Seat concentration & 0.17 & $-2.26^{* *}$ & -0.14 & 2.14 & $-7.05^{* * *}$ & 4.75 \\
& $(1.05)$ & $(0.98)$ & $(0.38)$ & $(1.25)$ & $(2.05)$ & $(3.74)$ \\
Share with $\geq 1$ rep. & & & & & & \\
& -0.40 & -0.49 & -0.11 & 0.26 & -1.09 & 1.08 \\
& $(0.24)$ & $(0.34)$ & $(0.10)$ & $(0.28)$ & $(0.73)$ & $(0.76)$ \\
Pop. concentration & & & & & & \\
& -3.06 & 4.02 & $-1.69^{* *}$ & 2.78 & 1.70 & -15.47 \\
& $(2.61)$ & $(4.25)$ & $(0.68)$ & $(1.97)$ & $(5.36)$ & $(17.31)$ \\
$\ln$ (population) & 0.17 & $-1.21^{* *}$ & $-0.35^{*}$ & -0.41 & 1.10 & 3.02 \\
& $(0.40)$ & $(0.54)$ & $(0.17)$ & $(0.33)$ & $(1.46)$ & $(2.73)$ \\
& & & & & & \\
& $0.39^{* *}$ & $0.64^{* *}$ & -0.05 & 0.15 & $1.19^{* * *}$ & -0.04 \\
& $(0.14)$ & $(0.28)$ & $(0.05)$ & $(0.11)$ & $(0.35)$ & $(0.45)$ \\
$\ln$ (road km) reform & 0.02 & 0.85 & $0.17^{*}$ & -0.22 & 0.52 & -0.28 \\
& $(0.27)$ & $(0.53)$ & $(0.09)$ & $(0.19)$ & $(0.69)$ & $(0.64)$ \\
$\ln$ (total spending per cap) & $0.21^{* * *}$ & 0.01 & 0.01 & 0.02 & 0.16 & 0.05 \\
& $(0.06)$ & $(0.08)$ & $(0.02)$ & $(0.04)$ & $(0.17)$ & $(0.31)$ \\
\hline$p$-value of Seat concentration & 0.894 & 0.120 & 0.720 & 0.290 & 0.016 & 0.174 \\
(Within) R-squared & 0.75 & 0.82 & 0.94 & 0.88 & 0.54 & 0.34 \\
No. of observations & 630 & 629 & 626 & 630 & 594 & 626 \\
Region fixed effects & Yes & Yes & Yes & Yes & Yes & Yes \\
El. period fixed effects & Yes & Yes & Yes & Yes & Yes & Yes \\
\hline
\end{tabular}

Note: All dependent variables are in log NOK per capita. The p-values of seat concentration reported are based on the wild bootstrap procedure of Cameron et al. (2008). Standard errors in parentheses and corresponding significance stars are adjusted for clustering at the region level.

allocation. To further verify that changes in the settlement pattern are not driving the results, I include two variables capturing population in 'central areas'26 and in densely populated areas. As shown in column (1) of Table 4, this has very little impact on the results.

Column (2) shows the results with more electoral control variables, including dummies for which party has the governor. The estimated effect of seat concentration decreases

\footnotetext{
${ }^{26}$ Centrality is a municipality-level measure defined as being within 60 minutes travel from an city or an urban settlement with at least 15,000 inhabitants (centrality code 2 from Statistics Norway), or within 75 minutes travel from the regional center or a city with at least 50,000 inhabitants (centrality code 3 ). The classification is from 2008.
} 
somewhat, but is still strongly statistically significant. The additional variables are weak predictors of investments in roads and transportation, but the shares of seats for the Centre Party (center-right, pro regional redistribution) and the Progress Party (rightwing, pro-road) go in the expected positive direction. The effects of the seat shares of the more enviromentalist Socialist party and Liberal party have the opposite sign. The estimated effects of female representatives and seat concentration among parties are also negative, but very imprecise. ${ }^{27}$

Columns (3) and (4) shows that the results are also robust to excluding outliers (defined by the 1st and 99th percentile) of the dependent variable and excluding the years after the 2010 road reform, respectively. Columns (5) and (6) show that the estimated effect of seat concentration is very similar when including a full set of year fixed effects (column 5) or aggregating the data on election periods (column 6). This is as expected, since variation in this variable (controlling for population structure) only comes from variation between election periods.

Since candidate nominations are decided by the parties, a potential concern is that geographic seat allocation within parties depends on the previous level of road investments. A partial investigation of this is to control for lagged investments, which I do in the Arellano and Bond (1991) differenced GMM specification reported in column (7). (This model is also estimated on election-period data.) The estimated effect of Seatconc $c_{r t}$ is still negative and only slightly lower than in the other specifications. The diagnostic tests show no sign of autocorrelation in the idiosyncratic disturbances or that the overidentifying restrictions are invalid. ${ }^{28}$

One should have in mind that parties have limited influence over the geographic composition of the regional council. They cannot perfectly predict how many seats they

\footnotetext{
${ }^{27}$ Svaleryd (2009) finds that more women in Swedish local councils leads to more spending on childcare and education, relative to elderly care. Borge (2005) finds that Norwegian municipalities where seats are concentrated among few parties have lower deficits.

${ }^{28}$ This is the standard specification using all available lags $(t-2$ to $t-7)$ of the dependent variable as instruments. However, with many instruments, the Hansen test of the overidentifying restrictions is weakened. If I limit the number of lags used, the estimated effect of seat concentration is somewhat stronger (about -8), and the $p$-value of the Hansen test is still very high.
} 
Table 4: Robustness checks: The effect of geographic seat concentration in the regional council on regional government investments in transportation: Robustness checks

\begin{tabular}{lrrrrrrr}
\hline & \multicolumn{1}{c}{$(1)$} & \multicolumn{1}{c}{$(2)$} & \multicolumn{1}{c}{$(3)$} & \multicolumn{1}{c}{$(4)$} & \multicolumn{1}{c}{$(5)$} & \multicolumn{1}{c}{$(6)$} & \multicolumn{1}{c}{$(7)$} \\
& \multicolumn{1}{c}{+} & \multicolumn{1}{c}{++} & - Outliers & $t<2010$ & Year FE & Collapse & \multicolumn{1}{c}{ GMM } \\
\hline Seat concentration & $-7.30^{* * *}$ & $-5.96^{* * *}$ & $-7.85^{* * *}$ & $-8.21^{* *}$ & $-6.82^{* * *}$ & $-6.85^{* * *}$ & $-5.89^{* *}$ \\
& $(2.16)$ & $(1.80)$ & $(2.11)$ & $(3.05)$ & $(2.12)$ & $(1.90)$ & $(2.52)$ \\
Share with $\geq 1$ rep. & & & & & & & \\
& $-1.17^{*}$ & $-1.15^{* *}$ & $-1.03^{*}$ & $-1.84^{*}$ & $-1.10^{*}$ & -0.90 & -0.71 \\
& $(0.56)$ & $(0.53)$ & $(0.55)$ & $(0.95)$ & $(0.62)$ & $(0.54)$ & $(0.49)$
\end{tabular}

Pop. share in central areas $\quad-1.78$

$\ln$ (Average pop. density) $\quad 0.03$

Leftwing reps.

Reps., Socialist party

Reps., Liberal party

Reps., Centre party

Reps., Progress party

Party concentration

Female representatives

Investments, previous period

$0.21^{* *}$

$p$-value of Seat conc.

(Within) R-squared

0.030

0.030

0.66

0.012

0.69

0.024

0.18

0.028

0.68

0.020
0.83

Number of instruments

$0.65-10.10$

(6)

$p$-value, Hansen test

No. of observations

Region fixed effects

El. period fixed effects

Year fixed effects

Dummies, governor's party

\begin{tabular}{|c|c|c|c|c|c|c|c|}
\hline & & & & & & & 1.000 \\
\hline & 630 & 630 & 617 & 540 & 630 & 162 & 126 \\
\hline & Yes & Yes & Yes & Yes & Yes & Yes & Yes \\
\hline & Yes & Yes & Yes & Yes & $\mathrm{No}$ & Yes & Yes \\
\hline & No & No & No & No & Yes & - & - \\
\hline party & No & Yes & No & No & No & No & No \\
\hline
\end{tabular}

Note: All specifications include the control variables in specification (5) in table 2. In columns (6) and (7), election periods are used as observational units instead of years. The p-values of seat concentration reported are based on the wild bootstrap procedure of Cameron et al. (2008). Standard errors in parentheses and corresponding significance stars are adjusted for clustering at the region level. 
will win, and hence who is elected. Also, before 2003, only 5/6 of the seats were allocated based on candidate rankings, while the last $1 / 6$ were given to (potentially very lowranked) candidates from municipalities which would otherwise not have a representative in the council. Arguably, the geographic allocation of seats would therefore be difficult to predict or influence pre-election.

\subsection{Alternative measures of political (de)fragmentation}

As discussed in the literature review in section 2, other measures of legislative structure are available. Depending on the institutional context, these measures might or might not capture the same underlying mechanism as the explanatory variables used in the analysis above. In Table 5, I show results when using one of the following measures as the main explanatory variable:

1. Council size, measured by the log number of council seats, $\ln \left(\sum_{i}\right.$ Seats $\left._{\text {irt }}\right)$

2. Seat concentration measured by the Herfindahl index: herf $r t=\sum_{i}\left(\frac{\text { Seats }_{\text {irt }}}{\sum_{i} \text { Seats }_{\text {irt }}}\right)^{2}$

3. A malapportionment index: malapp $_{r t}=\sum_{i}\left(\frac{\text { Seats }_{i r t}}{\sum_{i} \text { Seats }_{i r t}}-\frac{\text { Pop }_{i r t}}{\sum_{i} \text { Pop }_{i r t}}\right)^{2}$

(1.) is included as it is commonly used in the existing literature. Most regional governments have (voluntarily) changed the number of seats during the sample period. The Herfindahl index (2.) captures the influence of the municipalities with the most council members, but does not take into account relative population size like Seatconc $c_{r t}$ does. The malapportionment index (3.) is similar to the one used by Ansolabehere et al. (2002). It captures to what extent municipalities (potentially both large and small municipalities) are over- and under-represented relative to their populations.

Only specifications with region and election period fixed effects are reported. The effect of council size (column 1) is far from statistically significant, indicating that this measure is of little relevance in this context. The effect of the Herfindahl index (column 2) has the same sign as the effect of seat concentration, but is smaller and not significant 
Table 5: The effect on regional government investments in transportation using alternative measures of regional council size and geographic composition

\begin{tabular}{|c|c|c|c|c|c|c|}
\hline & $\begin{array}{c}(1) \\
\text { Council size }\end{array}$ & $\begin{array}{c}(2) \\
\text { Herfindahl }\end{array}$ & $\begin{array}{c}\text { (3) } \\
\text { Malapp. }\end{array}$ & $\begin{array}{c}(4) \\
\text { Council size }\end{array}$ & $\begin{array}{c}(5) \\
\text { Herfindahl }\end{array}$ & $\begin{array}{c}(6) \\
\text { Malapp. }\end{array}$ \\
\hline Main expl. variable & $\begin{array}{r}0.14 \\
(0.51)\end{array}$ & $\begin{array}{c}-2.57^{*} \\
(1.26)\end{array}$ & $\begin{array}{r}6.94^{* * *} \\
(2.32)\end{array}$ & $\begin{array}{r}0.57 \\
(0.61)\end{array}$ & $\begin{array}{r}-0.44 \\
(8.88)\end{array}$ & $\begin{array}{r}-0.48 \\
(8.91)\end{array}$ \\
\hline Seat concentration & & & & $\begin{array}{r}-7.62^{* * *} \\
(2.37)\end{array}$ & $\begin{array}{r}-6.72 \\
(9.75)\end{array}$ & $\begin{array}{r}-7.64 \\
(8.51)\end{array}$ \\
\hline Share with $\geq 1$ rep. & & & & $\begin{array}{c}-1.57^{*} \\
(0.80)\end{array}$ & $\begin{array}{r}-1.13 \\
(0.90)\end{array}$ & $\begin{array}{r}-1.13 \\
(0.90)\end{array}$ \\
\hline Pop. concentration & $\begin{array}{r}-2.32 \\
(4.00)\end{array}$ & $\begin{array}{r}-0.57 \\
(4.11)\end{array}$ & $\begin{array}{r}-2.29 \\
(3.88)\end{array}$ & $\begin{array}{r}1.11 \\
(4.10)\end{array}$ & $\begin{array}{r}1.32 \\
(5.67)\end{array}$ & $\begin{array}{r}1.78 \\
(6.05)\end{array}$ \\
\hline $\ln$ (population) & $\begin{array}{r}1.43 \\
(1.13)\end{array}$ & $\begin{array}{r}1.35 \\
(1.20)\end{array}$ & $\begin{array}{r}1.45 \\
(1.23)\end{array}$ & $\begin{array}{r}1.77 \\
(1.08)\end{array}$ & $\begin{array}{r}1.37 \\
(1.24)\end{array}$ & $\begin{array}{r}1.37 \\
(1.24)\end{array}$ \\
\hline $\ln ($ total spending per cap) & $\begin{array}{c}0.23^{*} \\
(0.13)\end{array}$ & $\begin{array}{r}0.23 \\
(0.14)\end{array}$ & $\begin{array}{c}0.25^{*} \\
(0.14)\end{array}$ & $\begin{array}{r}0.21 \\
(0.13)\end{array}$ & $\begin{array}{r}0.23 \\
(0.14)\end{array}$ & $\begin{array}{r}0.23 \\
(0.14)\end{array}$ \\
\hline 2010 reform & $\begin{array}{r}1.41^{* * *} \\
(0.30)\end{array}$ & $\begin{array}{r}1.42^{* * *} \\
(0.27)\end{array}$ & $\begin{array}{r}1.39^{* * *} \\
(0.28)\end{array}$ & $\begin{array}{r}1.40^{* * *} \\
(0.31)\end{array}$ & $\begin{array}{r}1.35^{* * *} \\
(0.30)\end{array}$ & $\begin{array}{r}1.35^{* * *} \\
(0.30)\end{array}$ \\
\hline $\ln ($ road km) & $\begin{array}{r}-0.05 \\
(0.62)\end{array}$ & $\begin{array}{r}-0.05 \\
(0.55)\end{array}$ & $\begin{array}{r}-0.01 \\
(0.57)\end{array}$ & $\begin{array}{r}-0.02 \\
(0.66)\end{array}$ & $\begin{array}{r}0.08 \\
(0.63)\end{array}$ & $\begin{array}{r}0.08 \\
(0.63) \\
\end{array}$ \\
\hline$p$-value of main expl. var. & 0.808 & 0.134 & 0.040 & 0.476 & 1.00 & 0.990 \\
\hline (Within) R-squared & 0.64 & 0.64 & 0.65 & 0.65 & 0.65 & 0.65 \\
\hline No. of observations & 630 & 630 & 630 & 630 & 630 & 630 \\
\hline Region fixed effects & Yes & Yes & Yes & Yes & Yes & Yes \\
\hline El. period fixed effects & Yes & Yes & Yes & Yes & Yes & Yes \\
\hline
\end{tabular}

Note: The main explanatory variable is reported in the column header. The dependent variable is log NOK per capita investments in roads and transportation by the regional government. The p-values of the main explanatory variable reported are based on the wild bootstrap procedure of Cameron et al. (2008). Standard errors in parentheses and corresponding significance stars are adjusted for clustering at the region level. 
at the 10 percent level based on a wild bootstrap $t$-test. This again indicates that the relative population size of a council member's home municipality is important, not just whether some municipalities have many representatives.

The effect of average malapportionment (column 3) is positive and statistically significant. This contrasts with the zero result of Ansolabehere et al. (2002) but is not surprising, given that the least populated municipalities are often the ones that are the most over-represented. In addition, this measure will have a higher value the more municipalities are not represented. Effectively, this implies that it combines the effects of the two variables used in the previous sections - seat concentration and the share of municipalities with at least one seat - into one effect.

These results illustrate that what is captured by the chosen measure of council size or composition depends on the features of the political systems included in the data. In some samples, the number of legislative seats could be strongly correlated with constituency size, and in others not. A large number of seats could also give more room for other interest groups (e.g. business sectors, professions, unions) which do not necessarily prefer higher spending on roads or other local public goods. Alternatively, as argued by Pettersson-Lidbom (2012), more seats could enable the elected politicians to curb the influence of such interest.

When we combine these models with the preferred explanatory variables from the previous sections, the estimated effect of seat concentration is far less precise in the last two models (columns 5 and 6). This reflects that these measures are highly correlated over time and partly capture the same features of the political system. However, the point estimate of the effects of seat concentration (and of the share of municipalities with at least one seat) is similar to those reported above. 


\section{Discussion}

The common-pool problem of centralized public spending in representative democracies implies that an elected representative only partly takes into account the alternative costs of allocating local public goods to his or her district. The model by Weingast et al. (1981) postulates that total spending on projects with local benefits will be higher the smaller is the geographic area (district) to which each representative belongs. This empirical prediction has not been tested directly in an electoral setting. Existing studies concern how spending is affected by legislature size, which does not necessarily capture the representatives' incentive to exploit the common pool.

Exploiting variation in the geographic allocation of council seats and and public spending in Norwegian regional governments, I find strong evidence that spending on roads decreases when more council members come from municipalities which are large in population. This is consistent with the hypothesis that representatives from larger municipalities to a larger degree take into the alternative cost of spending on local public goods. The effect is not driven by other characteristics of council members' hometowns or by partisan representation.

In my empirical investigation, it is implicitly assumed that the preferences of the regional council can be represented by an aggregate measure of the characteristics of its members. This does not rule out that council members form a majority under legislative bargaining (Baron and Ferejohn, 1989) or that members of a certain party or the ruling coalition are more influential. It only requires that a municipality is more likely to take part in the decision-making the more representatives it has. The anecdotal evidence in section 3.2 gives some support for the assumption that individual representatives matter.

These anecdotes were collected from local media, which illustrates another important point: Policies with locally concentrated benefits often get considerable local attention. While one possible theoretical interpretation is that this simply reflects strong preferences, it could also be considered a feature in itself. If we abandon the assumption that policy- 
makers are perfectly aware about all costs and benefits, an explanation for overspending on local public goods could be that these policies receive more attention than those which are of more general interest. One way to explore this further would be to study local media markets like Snyder and Strömberg (2010).

It should be emphasized that there could also be political inefficiencies which cause less spending on public infrastructure, and that there could be misallocations between different types of infrastructure projects. Several scholars have shown that the behaviour of political agents or institutional constraints can lead to underinvestment in productive public infrastructure (Leblanc et al., 2000; Besley et al., 2010; Kappeler et al., 2013). ${ }^{29}$ The results in my paper are not evidence that Norwegian regional governments (or other governments) in general spend too much on investments in and maintenance of roads. However, they document that the allocation of power between broader and more narrow geographic interest can have considerable impact on the allocation of public spending.

\section{Acknowledgements}

I would like to thank the two anonymous reviewers for their valuable comments on the previous version of the manuscript. This paper has also benefitted from comments by LarsErik Borge, Jon H. Fiva, Zohal Hessami, Jean Hindriks, Jo Thori Lind, Rune Sørensen and participants at the ITEA Annual Conference 2015. I would also like to thank the Norwegian Social Science Data Services (NSD) and especially Astrid Nilsen for providing the data, which are collected by Statistics Norway (SSB). NSD and SSB are not responsible for the analysis of the data or interpretations of the results.

\footnotetext{
${ }^{29}$ The results of Knight (2004), on the other hand, show that total spending on roads by the U.S. Congress is higher than the efficient level implied by the utility parameters estimated.
} 


\section{References}

Ansolabehere, S., Gerber, A., and Snyder, J. (2002). Equal votes, equal money: Courtordered redistricting and public expenditures in the American states. American Political Science Review, 96(4):767-778.

Arellano, M. and Bond, S. (1991). Some tests of specification for panel data: Monte Carlo evidence and an application to employment equations. The Review of Economic Studies, 58(2):277-297.

Baqir, R. (2002). Districting and government overspending. Journal of Political Economy, 110(6):1318-1354.

Baron, D. and Ferejohn, J. (1989). Bargaining in legislatures. American Political Science Review, 83(4):1181-1206.

Baskaran, T. (2013). Coalition governments, cabinet size, and the common pool problem: Evidence from the German states. European Journal of Political Economy, 32:356-376.

Besley, T. and Coate, S. (2003). Centralized versus decentralized provision of local public goods: a political economy approach. Journal of public economics, 87(12):2611-2637.

Besley, T., Persson, T., and Sturm, D. M. (2010). Political competition, policy and growth: theory and evidence from the US. The Review of Economic Studies, 77(4):1329-1352.

Borge, L.-E. (2005). Strong politicians, small deficits: evidence from norwegian local governments. European Journal of Political Economy, 21(2):325-344.

Borge, L.-E., Brueckner, J. K., and Rattsø, J. (2014). Partial fiscal decentralization and demand responsiveness of the local public sector: Theory and evidence from Norway. Journal of Urban Economics, 80:153-163. 
Borge, L.-E. and Tovmo, P. (2009). Myopic or constrained by balanced-budget rules? The intertemporal spending behavior of Norwegian local governments. FinanzArchiv: Public Finance Analysis, 65(2):200-219.

Bradbury, J. C. and Crain, W. M. (2001). Legislative organization and government spending: cross-country evidence. Journal of Public Economics, 82(3):309-325.

Burgess, R., Jedwab, R., Miguel, E., and Morjaria, A. (2013). The value of democracy: Evidence from road building in Kenya.

Cameron, A. C., Gelbach, J. B., and Miller, D. L. (2008). Bootstrap-Based Improvements for Inference with Clustered Errors. The Review of Economics and Statistics, 90(3):414427.

Castells, A. and Solé-Ollé, A. (2005). The regional allocation of infrastructure investment: The role of equity, efficiency and political factors. European Economic Review, 49(5):1165-1205.

Christensen, D. A., Midtbø, T., Ringkjøb, H.-E., Svåsand, L., and Aars, J. (2004). Ny personvalgordning og hva så? En analyse av kommune- og fylkestingsvalget i 2003. Rapport, Rokkansenteret.

DelRossi, A. F. and Inman, R. P. (1999). Changing the price of pork: the impact of local cost sharing on legislators' demands for distributive public goods. Journal of Public Economics, 71(2):247-273.

Drazen, A. and Eslava, M. (2010). Electoral manipulation via voter-friendly spending: Theory and evidence. Journal of Development Economics, 92(1):39-52.

Egger, P. and Koethenburger, M. (2010). Government spending and legislative organization: Quasi-experimental evidence from Germany. American Economic Journal: Applied Economics, 2(4):200-212. 
Eggers, A. C., Freier, R., Grembi, V., and Nannicini, T. (2015). Regression discontinuity designs based on population thresholds: Pitfalls and solutions.

Fiva, J. H. and Halse, A. H. (2015). Local favoritism under at-large proportional representation. CESifo Working Paper No. 5534, September 2015.

Gilligan, T. W. and Matsusaka, J. G. (1995). Deviations from constituent interests: The role of legislative structure and political parties in the states. Economic Inquiry, 33(3):383-401.

Guccio, C. and Mazza, I. (2014). On the political determinants of the allocation of funds to heritage authorities. European Journal of Political Economy, 34:18-38.

Hansen, C. B. (2007). Asymptotic properties of a robust variance matrix estimator for panel data when T is large. Journal of Econometrics, 141(2):597-620.

Hansen, F. H., editor (2001). SAMDATA Sykehus Rapport. Sykehusstruktur i endring. De lange linjer og utviklingen siste tiår. Report, SINTEF Unimed.

Helland, L. and Sørensen, R. J. (2009). Geographical redistribution with disproportional representation: a politico-economic model of Norwegian road projects. Public Choice, $139(1-2): 5-19$.

Horiuchi, Y. and Saito, J. (2003). Reapportionment and redistribution: Consequences of electoral reform in Japan. American Journal of Political Science, 47(4):669-682.

Jennes, G. and Persyn, D. (2015). The effect of political representation on the geographic distribution of income: Evidence using Belgian data. European Journal of Political Economy, 37:178-194.

Kappeler, A., Solé-Ollé, A., Stephan, A., and Välilä, T. (2013). Does fiscal decentralization foster regional investment in productive infrastructure? European Journal of Political Economy, 31:15-25. 
Knight, B. (2004). Parochial interests and the centralized provision of local public goods: evidence from congressional voting on transportation projects. Journal of Public Economics, 88(3):845-866.

Knight, B. (2005). Estimating the value of proposal power. American Economic Review, 95(5):1639-1652.

Knight, B. (2008). Legislative representation, bargaining power and the distribution of federal funds: Evidence from the US congress. The Economic Journal, 118(532):17851803.

Leblanc, W., Snyder Jr, J. M., and Tripathi, M. (2000). Majority-rule bargaining and the under provision of public investment goods. Journal of Public Economics, 75(1):21-47.

MacDonald, L. (2008). The impact of government structure on local public expenditures. Public Choice, 136(3-4):457-473.

Milesi-Ferretti, G. M., Perotti, R., and Rostagno, M. (2002). Electoral systems and public spending. The Quarterly Journal of Economics, 117(2):609-657.

Peltzman, S. (1976). Toward a more general theory of regulation. Journal of Law and Economics, 19(2):211-240.

Perotti, R. and Kontopoulos, Y. (2002). Fragmented fiscal policy. Journal of Public Economics, 86(2):191-222.

Persson, T. and Tabellini, G. (1994). Does centralization increase the size of government? European Economic Review, 38(3):765-773.

Persson, T. and Tabellini, G. (2000). Political economics. MIT Press Cambridge, Mass.

Pettersson-Lidbom, P. (2012). Does the size of the legislature affect the size of government? Evidence from two natural experiments. Journal of Public Economics, 96(3):269-278. 
Saarimaa, T. and Tukiainen, J. (2015). Common pool problems in voluntary municipal mergers. European Journal of Political Economy, 38:140-152.

Samuels, D. and Snyder, R. (2001). The value of a vote: malapportionment in comparative perspective. British Journal of Political Science, 31(4):651-671.

Schaltegger, C. A. and Feld, L. P. (2009). Do large cabinets favor large governments? evidence on the fiscal commons problem for Swiss Cantons. Journal of Public Economics, 93(1):35-47.

Snyder, J. M. and Strömberg, D. (2010). Press coverage and political accountability. Journal of Political Economy, 118(2):pp. 355-408.

Svaleryd, H. (2009). Women's representation and public spending. European Journal of Political Economy, 25(2):186-198.

Weingast, B. R., Shepsle, K. A., and Johnsen, C. (1981). The political economy of benefits and costs: A neoclassical approach to distributive politics. The Journal of Political Economy, 89(4):642-664.

Wright, G. (1974). The political economy of new deal spending: An econometric analysis. The Review of Economics and Statistics, 56(1):30-38. 


\section{Appendix A}

Table A.1: Descriptive statistics: Spending variables (NOK 2014 per capita)

\begin{tabular}{lccccc}
\hline \hline \multicolumn{1}{c}{ Variable } & Mean & Std. Dev. & Min. & Max. & N \\
\hline Total spending per capita & 18670.7 & 6383.88 & 7689.43 & 41091.05 & 630 \\
Operating expenditures, schools & 5010.49 & 1354.46 & 2471.65 & 8882.87 & 630 \\
Oper. exp., roads/transportation & 2227 & 1301.55 & 576.42 & 8336.78 & 630 \\
Oper. exp, roads & 863.92 & 700.73 & 122.24 & 4581.25 & 629 \\
Oper. exp, culture & 419.63 & 237.49 & 109.79 & 1485.43 & 630 \\
Investments, schools & 472.25 & 455.96 & 0 & 2679.19 & 630 \\
Investments, roads/transportation & 579.07 & 842.86 & 3.35 & 6644.66 & 630 \\
Investments, roads (1980-2012) & 468.15 & 653.12 & 3.35 & 6636.5 & 594 \\
\hline
\end{tabular}


Table A.2: Descriptive statistics: Political and geographic variables

\begin{tabular}{lcccc}
\hline \hline \multicolumn{1}{c}{ Variable } & Mean & Std. Dev. & Min. & Max. \\
\hline Seat concentration & 0.11 & 0.05 & 0.04 & 0.25 \\
Municipalities with $\geq$ 1 seat & 0.89 & 0.15 & 0.48 & 1 \\
Area share per rep. & 0.05 & 0.02 & 0.02 & 0.1 \\
Regional road share per rep. & 0.06 & 0.02 & 0.03 & 0.12 \\
Reps. from island muncipalities & 0.09 & 0.12 & 0 & 0.4 \\
Leftwing representatives & 0.42 & 0.1 & 0.23 & 0.66 \\
Female representatives & 0.39 & 0.07 & 0.19 & 0.51 \\
Party concentration & 0.22 & 0.05 & 0.13 & 0.38 \\
Reps. from Socialist party (SV) & 0.07 & 0.04 & 0.02 & 0.2 \\
Reps. from Center party (Sp) & 0.11 & 0.06 & 0.02 & 0.33 \\
Reps. from Progress party (Frp) & 0.1 & 0.06 & 0 & 0.26 \\
Regional population (1000) & 219.23 & 106.81 & 72.40 & 575.76 \\
Population concentration & 0.14 & 0.08 & 0.05 & 0.36 \\
Pop in central areas (share) & 0.73 & 0.3 & 0 & 1 \\
Regional roads in region (km) & 1644.92 & 678.27 & 623 & 4109 \\
Area of region (square km.) & 16878.86 & 11140.49 & 2148.23 & 45761.88 \\
Coastline (km) & 4622.33 & 5350.52 & 0 & 23021 \\
\multicolumn{1}{c}{ N } & & & & \\
\hline
\end{tabular}

